\title{
Pengolahan Air Minum Sistem Reverse Osmosis di Pesantren Hidayatullah Gowa
}

\author{
Muhammad Syahid*, Mukhtar Rahman, Nasruddin Azis, Syahrier Arief, Irwan Fathar \\ Departement Teknik Mesin, Fakultas Teknik Universitas Hasanuddin \\ * syahid@unhas.ac.id
}

\begin{abstract}
Abstrak
Kegiatan ini bertujuan untuk meningkatkan kualitas air minum dengan sistem reverse osmosis yaitu pengolahan penyaringan air untuk menetralisir rasa, bau dan zat berbahaya yang terkandung di dalam air hingga 0,0001 mikron. Salah satu kendala yang dihadapi oleh Pesantren Hidayatullah, Desa Timbuseng, Kecamatan Pattalassang, Kabupaten Gowa yaitu sangat bergantung pada pengelolaan secara tradisional dan penggunaan jasa penyedia air galon, sehingga membutuhkan tenaga yang banyak dan waktu yang cukup lama serta biaya tinggi jika disediakan dengan membeli air galon. Dengan Kegiatan Pengabdian Mayarakat pemberian bantuan reverse osmosis ini diharapkan bisa menjadi alternatif penyediaan air minum yang layak konsumsi sehingga staf/santri dapat terhindar dari resiko penyakit dan mengefisiensi waktu dan biaya yang dikeluarkan untuk membeli air galon.
\end{abstract}

Kata Kunci: Pesantren; Air minum; Pengabdian masyarakat; Reverse osmosis; Efisien.

\begin{abstract}
This activity aims to improve the quality of drinking water with a reverse osmosis system that is water filtration treatment to neutralize the taste, odor and hazardous substances contained in water up to 0,0001 microns. One obstacle faced by Hidayatullah Islamic Boarding School, Timbuseng Village, Pattalassang Subdistrict, Gowa Regency is very dependent on traditional management and the use of gallon water supply services, so that it requires a lot of energy and a long time and high costs if provided by buying gallon water. With Community Service Activities this reverse osmosis assistance is expected to be an alternative supply of drinking water that is suitable for consumption so that staff / students can avoid the risk of disease and make time and money spent to buy gallon water efficient.
\end{abstract}

Keywords: Boarding School; Mineral Water; Community Service; Reverse Osmosis; Efficient.

\section{Pendahuluan}

Sejak awal, air telah menjadi kebutuhan utama yang sangat penting bagi manusia dan makhluk hidup. Air merupakan kebutuhan dasar manusia. Lebih dari 70\% tubuh manusia terdiri dari air (75\% di otak, $75 \%$ di jantung, $86 \%$ di paru-paru, $86 \%$ di hati $83 \%$ di ginjal, $75 \%$ di otot, dan $83 \%$ di darah). Air diperlukan oleh semua organ tubuh agar dapat berfungsi dengan sempurna, misal: dalam proses pembuangan racun (toxic), pelicin bagi sendi-sendi, membantu proses pencernaan, menstabilkan suhu tubuh, dan memperlancar proses metabolisme tubuh.

Saat ini, air yang biasa dikonsumsi oleh masyarakat telah banyak mengandung zat pencemar, baik zat organik maupun zat anorganik. Zat-zat polutan tersebut mengakibatkan menurunnya kualitas air minum untuk kebutuhan konsumsi. Kualitas air minum yang tidak sehat tersebut 
menyebabkan proses metabolisme sel tidak sempurna dan menghasilkan sedikit energi bagi aktifitas sel. Nutrisi yang terbuang akibat tidak normalnya proses metabolisme akan terbuang dan terakumulasi sehingga menjadi racun bagi tubuh yang pada akhirnya menyebabkan perkembangan berbagai macam penyakit. Meskipun air mudah untuk ditemukan, namun kenyataannya tidak semua daerah mempunyai sumber daya air yang baik.

Karena permasalahan dan kebutuhan utama akan air, telah tercipta banyak sistem pengolahan air antara lain adalah: Disinfektansi (dimasak, Chlorinisasi, Ozonisasi, Sinar Ultra Violet), Destilasi, Mikrofiltrasi, dan Filterisasi (Activated Alumina, Activated Carbon, Anion \& Cation Exchange). Salah satu yang terbaik adalah dengan menggunakan teknologi Reverse Osmosis (RO).

Reverse Osmosis merupakan suatu metode pembersihan melalui membran semi permeable. Pada proses dengan membran, pemisahan air dari pengotornya didasarkan pada proses penyaringan dengan skala molekul, dimana suatu tekanan tinggi diberikan melampaui tarikan osmosis sehingga akan memaksa air melalui proses osmosis terbalik dari bagian yang memiliki kepekatan tinggi ke bagian yang mempunyai kepekatan rendah. Selama proses tersebut terjadi, kotoran dan bahan yang berbahaya akan dibuang sebagai air tercemar (limbah). Molekul air dan bahan mikro yang berukuran lebih kecil dari Reverse Osmosis akan tersaring melalui membran. Teknologi membran Reverse Osmosis dapat menghasilkan air minum berkualitas tinggi dengan cepat karena menggunakan tenaga pompa. Sistem membran reverse yang dipakai dapat berupa membran hollow fibre, lempeng/plate atau berupa spiral wound. Membran ini mampu menurunkan kadar zat pencemar hingga 95-98\%. Air hasil olahan sudah bebas dari bakteri dan dapat langsung diminum.

Permasalahan ketersediaan air minum juga dialami oleh Pesantren Hidayatullah, Kabupaten Gowa. Penyediaan air minum tidak sebanding dengan banyaknya jumlah santri serta staff yang berada pada pesantren tersebut, banyaknya tenaga dan waktu yang dibutuhkan jika menggunakan metode tradisional dan juga biaya yang tinggi jika ingin menggunakan jasa penyedia air galon, pedahal air siap minum harus selalu tersedia mengingat banyaknya santri dan staff yang tinggal di dalam pesantren tersebut. Selain keterbatasan waktu dan tenaga kerja, kualitas air minum yang disediakan dengan menggunakan metode tradisional masih belum bisa dikatakan jernih sehingga dapat menimbulkan resiko penyakit yang dapat menimpa santri/staff.

Berkaitan dengan hal tersebut, permasalahan yang dihadapi oleh Pesantren Hidayatullah, Kabupaten Gowa adalah sebagai berikut:

- Dibutuhkan pengetahuan penyediaan air bersih dengan intervensi teknologi pada santri/staff pesantren untuk menjamin kesehatan para santri/staff pesantren;

- Dibutuhkan intervensi teknologi terutama teknologi Reverse Osmosis untuk meningkatkan kualitas air bersih; dan

- Pelatihan penggunaan dan perawatan mesin reverse osmosis yang dapat dijangkau oleh santri/staff pesantren. 
Permasalahan tersebut dapat diatasi dengan melakukan kerjasama dengan pihak yang terkait dan memiliki kepakaran dan pengalaman dalam penggunaan mesin reverse osmosis untuk penyediaan air bersih dalam hal ini perguruan tinggi memiliki tugas berpartisipasi dalam membantu menyelesaikan persoalan yang ada sebagai wujud Tridharma Perguruan Tinggi yaitu pengabdian pada masyarakat.

\section{Metode Pelaksanaan}

Kegiatan ini dilaksanakan pada tanggal 19 September 2019 yang diawali dengan studi kondisi ketersediaan dan kualitas air di Pesantren Hidayatullah Gowa, studi tersebut menjadi pertimbangan didalam menentukan kapasitas dan jumlah tahapan penyaringan reverse osmosis yang dibuat. Selain pemberian bantuan reverse osmosis juga dirangkaikan dengan memberikan pengetahuan bagaimana pengoperasian dan perawatan reverse osmosis serta pentingnya mengkonsumsi air minum yang layak kosnsumsi.

\section{Hasil Dan Pembahasan}

\subsection{Pembuatan Pengolahan Sistem Reverse Osmosis}

Sistem reverse osmosis meliputi penampungan awal hingga tahap pengolahan dengan spesifikasi yang direncanakan yaitu:

- Kapasitas penampungan awal 550 liter

- Kapasitas sistem reverse osmosis 378 liter/ hari

- Dimensi sistem reverse osmosis $40 \mathrm{~cm}$ x $25 \mathrm{~cm} \mathrm{x} 45 \mathrm{~cm}$

- Jumlah tahapan penyaringan 6 buah

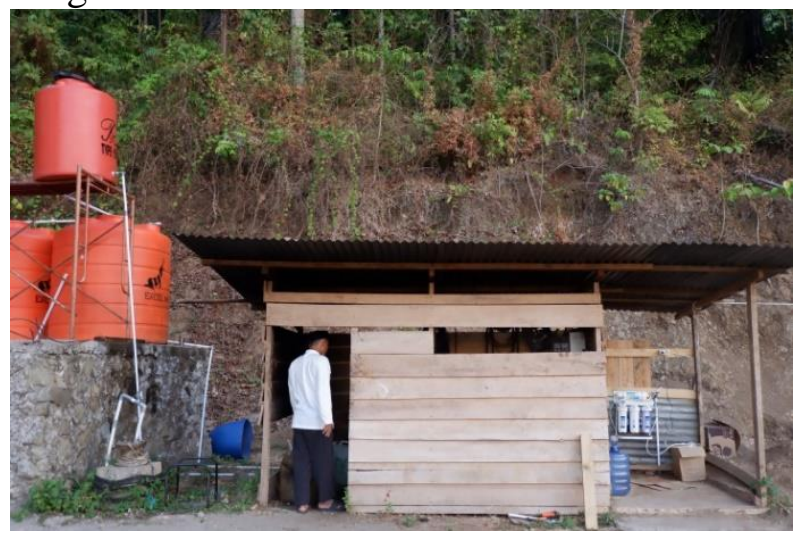

Gambar 1. Sistem Reverse Osmosis

Penampungan awal sistem reverse osmosis menggunakan tandon berkapasitas 550 liter dengan rangka terbuat dari besi yang dapat dibongkar pasang untuk memudahkan pemindahan dan perakitan. Sistem reverse osmosis dibuat dengan 6 buah tahapan penyaringan untuk menetralisir rasa, bau dan menyaring zat-zat berbahaya seperti pasir, debu dan zat berbahaya lainnya hingga 0,0001 mikron. Untuk membantu proses penyaringan, dipasang pompa bertekanan dengan kebutuhan daya 30 watt untuk memudahkan sirkulasi pada tahapan penyaringan. Kelemahan dari 
pemasangan pompa ini adalah tekanan pada suction dan discharge pompa tidak konstan bergantung dari tekanan yang masuk ke penyaringan tahap awal. Oleh karena itu dilakukan penambahan low pressure switch dan high pressure switch untuk memutuskan arus listrik pompa jika tekanan air kurang dari 5 psi atau lebih dari 38 psi.

\subsection{Penyuluhan dan Pemberian Bantuan Reverse Osmosis}

Kegiatan penyuluhan dan pemberian bantuan reverse osmosis dilaksanakan di Pesantren Hidayatullah, Desa Timbuseng, Kecamatan Pattalassang, Kabupaten Gowa, pada tanggal 19 September 2019. Kegiatan yang diawali dengan diskusi pengelolaan air di Pesantren Hidayatullah, Kabupaten Gowa. Pada awalnya pengelola Pesantren Hidayatullah mengolah air minum dengan memasak berjam-jam dan jika kebutuhan akan air minum meningkat, pihak pengelola akan menggunakan jasa penyedia air galon disekitar pesantren. Penyuluhan pengolahan air minum sistem reverse osmosis seperti yang terlihat pada Gambar 2.

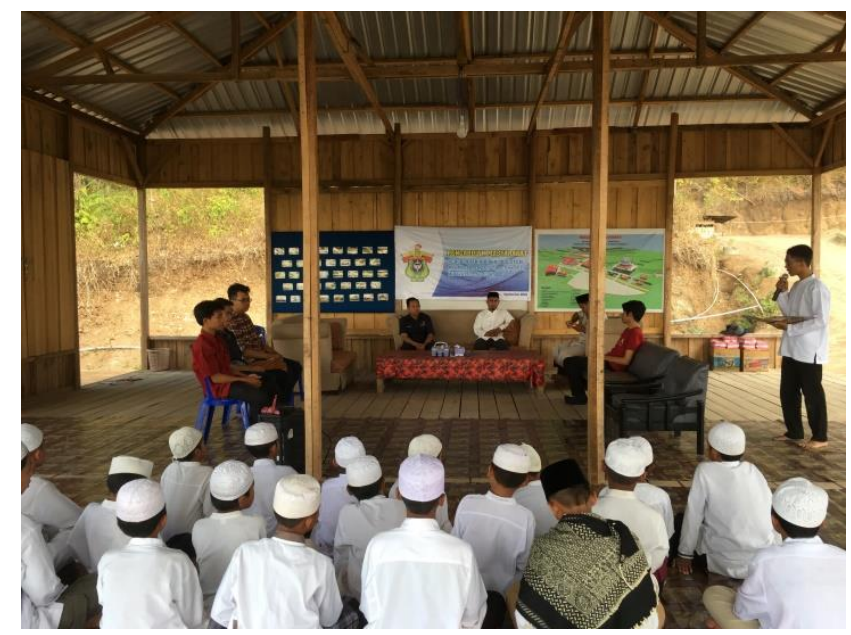

Gambar 2. Penyuluhan Pengolahan Air Minum Sistem Reverse Osmosis

Pemberian bantuan Reverse Osmosis, demonstrasi penggunaan dan perawatannya dilakukan dengan melibatkan masyarakat di Pesantren Hidayatullah. Hal penting yang dijelaskan adalah memperhatikan kondisi tekanan air yang masuk pada suction pompa. Hal ini untuk menjaga pompa dapat beroperasi sesuai dengan tekanan kerja pompa yaitu kurang dari 5 psi atau lebih dari 38 psi sehingga memudahkan didalam proses penyaringan. 

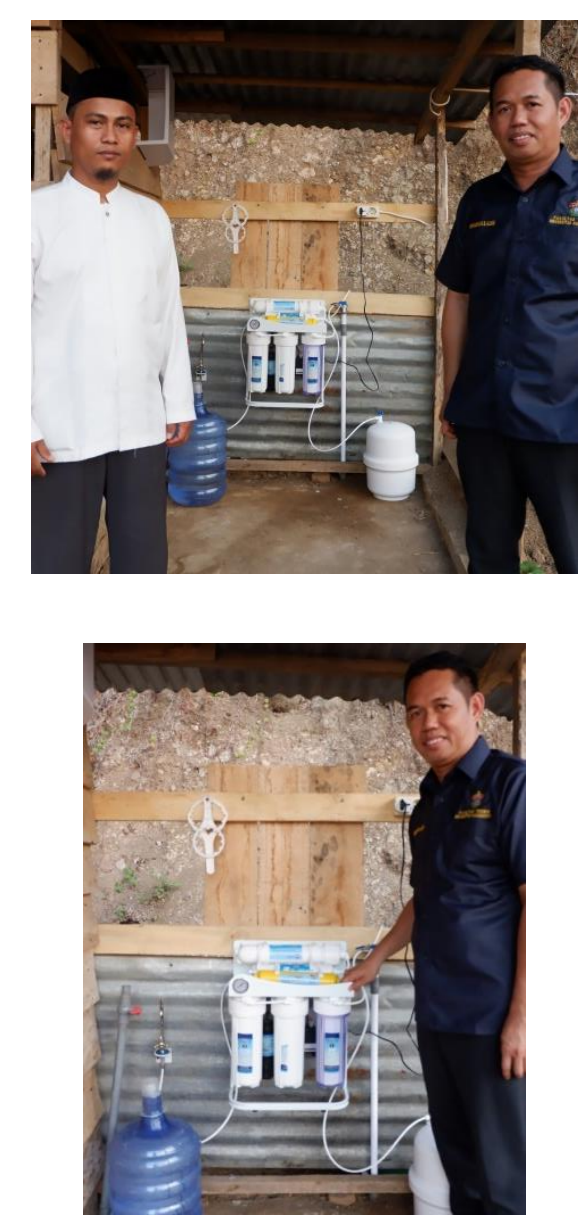

Gambar 3. Pemberian Penjelasan tentang Penggunaan Reverse Osmosis

Hal lain yang dijelaskan adalah pentingnya penggantian saringan yang digunakan secara berkala untuk menjaga kualitas air minum yang dihasilkan setiap kali proses penyaringan berlangsung. Jika penggantian saringan tidak dilakukan secara berkala air minum yang dihasilkan tidak akan sesuai dengan standar baku mutu dan sistem reverse osmosis akan mengalami penyumbatan.

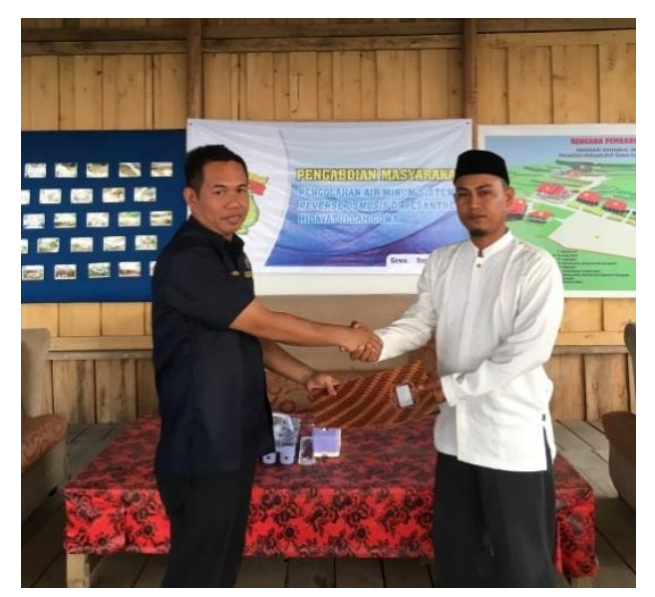


Gambar 4. Serah Terima Bantuan Reverse Osmosis dengan Ketua Yayasan Pondok Pesantren Hidayatullah Gowa

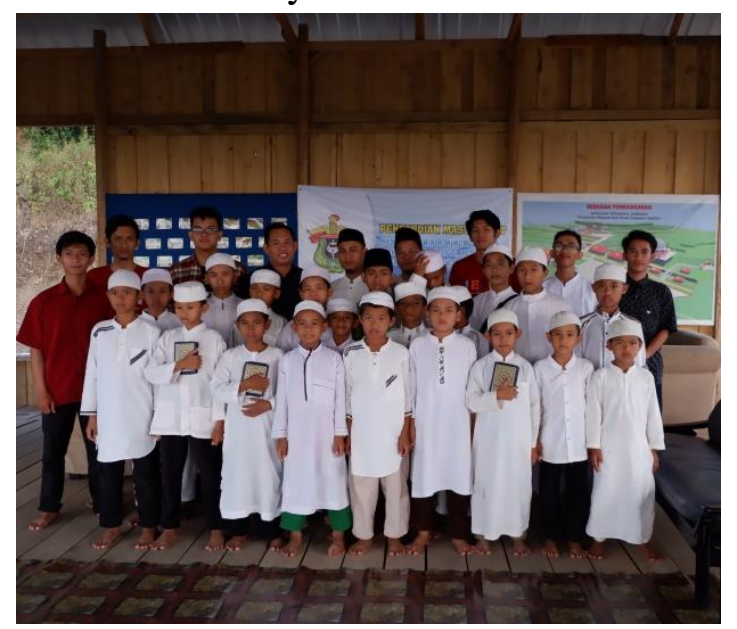

Gambar 5. Foto Bersama Pengurus Yayasan dan Santri Pondok Pesantren Hidayatullah Gowa

\section{Kesimpulan}

Masyarakat Pesantren Hidayatullah Gowa memahami pentingnya mengkonsumsi air yang layak minum, namun masih ditemukan pengelolaan air dengan cara tradisional yang kualitasnya tidak dapat dikatakan layak untuk dikonsumsi karena banyaknya kontaminasi dari luar. Masyarakat Pesantren Hidayatullah Gowa berterima kasih dengan adanya bantuan reverse osmosis karena sangat membantu didalam penyediaan air minum yang layak dan mengurangi pengeluaran biaya didalam penggunaan jasa penyedia air galon.

\section{Ucapan Terima Kasih}

Terima Kasih sebesar-besarnya kepada staf/santri Pesantren Hidayatullah, Desa Timbuseng, Kecamatan Pattalassang, Kabupaten Gowa khususnya Ketua Yayasan Pondok Pesantren Hidayatullah Gowa karena telah menerima dan berkerjasama dalam menyelenggarakan kegiatan ini sehingga dapat berjalan dengan lancar.

\section{Daftar Pustaka}

Hartomo, A.J., Widiatmoko M.C. (2006). Teknologi Membran Pemurnian Air. Yogyakarta : Andi Offset.

Linsley, R.K. dan J. Franzini. (1985). Teknik Penjernih Air. Penerjemah Djoko Sasongko. Jakarta: Erlangga.

Said, N.I. (2008). Pengolahan Payau Menjadi Air Minum dengan Teknologi Reverse Osmosis. Direktorat Teknologi Lingkungan-BPPT.

Soedjono, E.S., Dewi, L.K, Azfah, R.A. (2012). Rancang Bangun Alat Pemurni Air Payau Sederhana Dengan Membran Reverse Osmosis Untuk Memenuhi Kebutuhan Air Minum Masyarakat Miskin Daerah Pesisir. Institut Teknologi Sepuluh November, Surabaya.

Wenten, I.G. (1999). Teknologi Membran Industrial. Institut Teknologi Bandung, Bandung. 